\title{
DIALEKTIKA AGAMA DAN BUDAYA DALAM TRADISI SELAMATAN PERNIKAHAN ADAT JAWA DI NGAJUM, MALANG
}

\author{
Roibin \\ UIN Maulana Malik Ibrahim Malang \\ email: roibinuin@gmail.com
}

\begin{abstract}
Empirical analysis on the religion and culture dialectics in the selamatan ritual of Javanese wedding has not been explored by teologist, social scientist or religion anthropologist. Their studies on such a case mostly concern with ontologicalphilological text analysis not directly related with the religious tradition and socio-culture which is more dynamic and realistic. This study employs social definition paradigm and phenomenological theory approach limited to the dialectic pattern between religion and myth in the ritual selamatan of Javanese wedding. The data were collected though interviewing and observing religious leaders, ethnic leaders, and Muslim preacher in Ngajum, Malang. The study found two models of dialectic pattern namely theological-compromistic and theological-humanistic. The earlier describes the theological shift from emotionalnaturalistic to rational-formalistic. The later describes the theological shift from personal to social awareness theology.
\end{abstract}

Telaah empirik seputar pola dialektika antara agama dan budaya dalam kasus ritual selamatan pernikahan adat Jawa, belum banyak dilakukan oleh para pakar agama, ilmuan sosial, maupun ilmuan antropolog agama. Kajian mereka terhadap kasus ini pada umumnya masih menekankan pada objek pembacaan teks secara ontologis-filologis, yang tidak bersinggungan secara langsung terhadap tradisi keagamaan dan budaya masyarakat yang lebih dinamis dan realistis. Penelitian ini menggunakan paradigma definisi sosial dan pendekatan teori fenomenologis, yang dibatasi pada pola dialektika antara agama dan mitos dalam kasus ritual selamatan pernikahan adat Jawa. Data diperoleh dengan cara menginterview dan mengobservasi para tokoh agama, tokoh adat, dan para da'i yang ada di Ngajum, Malang. Penelitian ini menemukan dua model yaitu pola dialektika teologis-kompromistik dan pola dialektika teologis-humanistik. 
Pola dialektika pertama, menggambarkan pergeseran teologis, dari teologi yang bersifat emosional-naturalistik menuju teologi yang bersifat rasional-formalistik. Adapun pola teologis-humanistik menggambarkan adanya pergeseran teologi yang bersifat personal menuju teologi yang berkesadaran sosial.

Keywords: dialectics, religion, culture, tradition, selamatan wedding

\section{Pendahuluan}

Secara umum, fenomena dialektika agama dan budaya yang terjadi secara natural dan intens di masyarakat Jawa, tidak sedikit telah melahirkan sikap keagamaan masyarakat muslim yang sangat variatif. Mulai dari agama sebagai hal yang diyakini (sistem nilai), difahami (sistem kognisi), hingga dipraktekkan (sistem afeksi). Pentahapan tersebut tidak saja muncul pada tataran keyakinan saja, tetapi pada setiap ketiga tahapan di atas melahirkan perbedaan ekspresi keagamaan yang cukup signifikan.

Sebagai contoh ilustrasi, bagaimana agama diyakini, telah memunculkan sikap keagamaan dari sebagian komunitas muslim tertentu yang bersemangat untuk melakukan purifikasi Islam dari kemungkinan praktik akulturasi budaya setempat, sementara sebagian yang lainnya berupaya membangun pola dialektika antar keduanya secara harmonis dan intensif. Masing-masing komunitas di atas telah memiliki keyakinan bahwa hakikat Islam yang mereka yakini tersebut berasal dari samawi, sementara yang lain meyakininya bahwa Islam itu adalah manifestasi perjumpaan antara keduanya. Tidak dapat dipungkiri, fakta tersebut terjadi secara sistematik dari waktu ke waktu. Terlepas bagaimana kebenaran keyakinan masing-masing pemahaman, yang jelas relasi keduanya semakin menjustifikasi suburnya praktik pola akulturasi maupun sinkretisasi agama.

Keadaan di atas mengindikasikan bahwa efek tradisi lokal (low tradition) semakin menampakkan pengaruhnya terhadap karakter asli agama formal (high tradition), demikian juga sebaliknya. Dalam hal ini, agama dan budaya tidak lagi dapat dikatakan mana yang lebih dominan, budaya sebagai produk agama atau agama sebagai produk budaya. Ini merupakan potret relasi yang saling berkelindan dan saling mempengaruhi.

Keragaman perilaku sosial keberagamaan di atas, tentu tidak berarti terjadi secara monolitik yang ingin mempertahankan keadaan dirinya secara final, melainkan tidak menutup kemungkinan masing-masing entitas akan mengalami pergeseran paradigmatik, sebab pada saat yang sama mereka senantiasa berhadapan dengan proses eksternalisasi, objektivasi, maupun internalisasi. Siapa membentuk apa, sebaliknya apa mempengaruhi siapa. 
Bagaimana masyarakat memahami agama hingga bagaimana peran-peran lokal mempengaruhi perilaku sosial keberagamaan mereka (Waters, 1994: 35).

Fenomena dialektika di atas secara empirik dapat diamati secara riil, dalam tradisi keberagamaan masyarakat muslim lokal, terutama pada pola relasi antara nilai-nilai sosial budaya selamatan perkawinan adat lokal dengan nilai-nilai sosial perkawinan budaya mainstream Islam.

Berangkat dari beberapa permasalahan di atas, makalah ini akan memfokuskan kajiannya pada bagaimana pola dialektika agama dan budaya dalam kasus ritual selamatan pernikahan adat Jawa di Ngajum Malang.

\section{Selamatan: Ritual Pernikahan Adat Jawa}

Fenomena selamatan pernikahan adat Jawa telah berlangsung selama berabad-abad. Dari waktu ke waktu, adat selamatan pernikahan Jawa tersebut melakukan fungsi pengulangan dan secara otomatis telah melegitimasi konstruk tradisi sebelumnya. Proses pengulangan itu secara terus menerus dilakukan hingga melahirkan suatu kebiasaan atau mitos.

Oleh karena itu, tradisi atau adat selamatan pernikahan intinya adalah warisan masa lalu yang dilestarikan secara terus menerus hingga sekarang. Warisan masa lalu itu dapat berupa nilai, norma, sosial, pola kelakukan dan adat kebiasaan lain yang merupakan eksistensi dari berbagai aspek kehidupan. Dengan demikian selamatan pra pernikahan bagi masyarakat adat Jawa difahami sebagai elemen yang sangat penting hubungannya dengan upaya mengantarkan terbentuknya hubungan cinta kasih yang tulus antara pemuda dan pemudi, yaitu perempuan dan laki-laki.

Sementara itu tradisi atau adat selamatan pernikahan adalah warisan masa lampau yang sampai kepada kita dan masuk ke dalam kebudayaan yang sekarang berlaku. Dengan demikian bagi Hanafi tradisi bukan sekedar perilaku mempertahankan dan membudayakan sejarah, tetapi sekaligus merupakan sejarah yang memiliki kontribusi bagi zaman kekinian dalam berbagai tingkatannya (Bawani, 1990: 23).

Oleh karena itu semua yang telah menjadi kebiasaan masyarakat itu mayoritas menjadi kepercayaan mitis yang sakral dan suci. Inilah yang pada gilirannya, kebiasaan tradisi tersebut tanpa terasa telah menjadi sistem nilai (pattern for behavior/pedoman) bagi masyarakat populis pada umumnya. Sistem nilai itu tidak jarang telah menjadi pedoman hidup mereka yang tingkat sakralitasnya kadang melebihi sistem nilai dari teksteks keagamaan formal lainnya. 
Hal mendasar dari terminologi makna tradisi selamatan pernikahan adat Jawa yang tidak dapat dilepaskan adalah adanya relasi atau kaitan yang saling memberikan kontribusi antara masa lalu dengan masa kini, baik berupa nilai, norma, sosial, pranata kehidupan maupun nilai-nilai lain dalam kehidupan secara makro. Oleh karena itu, terminologi tradisi ini dalam praktiknya telah menyusup ke dalam berbagai eksistensi yang lintas. Jika perdebatan itu menyangkut tradisi Islam maupun tradisi Kristen misalnya, ini berarti tanpa sadar telah menyebut serangkaian ajaran/ doktrin, baik Islam maupun Kristen yang telah dilakukan ratusan maupun ribuan tahun yang lalu, namun telah hadir dan memiliki makna pedoman bagi kehidupan masa kini.

Tradisi selamatan pernikahan Jawa dalam pengertian yang paling sederhana dapat difahami sebagai sesuatu yang ditransmisikan atau diwariskan dari masa lalu ke masa kini, baik oleh Islam, agama-agama non Islam maupun aliran lokal setempat (Pranowo, 1998: 4) yang hingga kini dapat dirasakan eksistensinya. Oleh karena itu jika pemahaman tradisi yang telah terelaborasi di atas dikaitkan dengan fakta tradisi ritual-ritual selamatan pernikahan yang berkembang di kalangan masyarakat Jawa, maka dapat ditarik suatu pemahaman baru bahwa ritual-ritual adat selamatan dalam pernikahan Jawa adalah suatu ritual pernikahan yang telah ditransmisikan dari masa lalu hingga kini yang semangat atau ruhnya tetap dirasakan di hati masyarakat populis pada umumnya.

Atas dasar itu tradisi selamatan dalam pernikahan Jawa adalah praktik ritual pernikahan yang telah menggenerasi, turun-temurun, menjadi keyakinan mistis yang tidak sederhana proses kognisinya. Bagi generasi baru yang hadir dengan kultur barunya untuk dapat berkembang di suatu tradisi yang telah ada dan untuk menyapa lebih jauh terhadap keberadaan tradisi tersebut tidaklah sederhana, apalagi jika hendak melakukan perubahan-perubahan di dalamnya. Oleh karenanya mereka yang sukses berinteraksi dengan tradisi atau adat adalah mereka yang menyesuaikan dengan dunia kultural yang masih eksis di dalamnya.

\section{Dimensi Mistis dan Religius Selamatan dalam Pernikahan Adat Jawa}

Secara mistis, ritual selamatan khususnya dalam pernikahan adalah ritual suci dan sakral yang keberadaannya sangat mendasar bagi sukses tidaknya kegiatan pernikahan tersebut. Keyakinan mitos tentang ruh para leluhur yang sudah meninggal mendahului kita dan beberapa makhluk ghaib lainnya utamanya di Ngajum Malang, telah memunculkan motif untuk melakukan tindakan 
upacara-upacara dan keyakinan baru bagi masyarakat ngajum (Durkheim, 1976: 24-42). Bentuk riil upacara itu misalnya dengan menyelenggarakan sesajen yang kini berubah menjadi selamatan.

Tindakan ritual dalam bentuk selamatan itu ternyata tidak saja berarti pemberian sesajen kepada arwah para leluhur, nenek moyang, dan para dewa melalui sarana bahan makanan yang dikeramatkan dengan do'a-do'a dan mantra jawa, tetapi juga ada tindakan lain yang disebut dengan caos hormat marang Kyai setempat, sebagai tokoh yang diharapkan ikut membantu kelancaran pernikahan adat tersebut. Selamatan dipahami sebagai bentuk rasa syukurnya sekaligus ucapan caos hormat atas segala berkah dengan perantara (wasilah) kyai spiritual hingga mengantarkan kesuksesan hidupnya (Sofwan, 2011: 88).

Selamatan adalah versi upacara keagamaan masyarakat jawa secara umum. Selamatan melambangkan kesatuan mistis dan kesatuan sosial mereka yang ikut serta di dalamnya. Handai tolan, tetangga, rekan kerja, sanak keluarga, arwah setempat, nenek moyang yang telah meninggal, dewa-dewa, semuanya duduk bersama mengelilingi satu ruang dan karena itu terikat dalam kelompok sosial tertentu yang diwajibkan untuk tolong-menolong dan bekerja sama. Selamatan juga merupakan media untuk mempertemukan berbagai aspek kehidupan sosial dengan suatu cara untuk memperkecil ketidakpastian maupun konflik (Geertz, 1989: 13).

Selamatan pada hakikatnya adalah ritual atau upacara makan yang terdiri atas sesajian, makanan simbolik, sambutan resmi, dan mantra-mantra/ do'a (Beatty, 2001: 35). Di setiap pusat keseluruhan sistem agama Jawa, pasti terdapat sebuah ritus yang formal, sederhana, dan jauh dari keramaian, ritus itu adalah ritus selamatan (Geertz, 1960: 11). Karenanya, tradisi selamatan apapun hajatnya adalah ritual asli/ inti agama Jawa yang berakar dari tradisi pedesaan animis (Beatty, 2001: 41-42).

Sementara itu, selamatan adalah produk interpretasi teks-teks Islam yang berpijak pada aksesoris dan tindakan ritual kejawen yang dikenali dan disepakati bersama oleh orang-orang muslim yang lebih luas (Woodward,1988: 54-89). Dalam pandangannya, selamatan adat pernikahan disamping untuk memenuhi adat Jawa, di dalamnya juga mengandung do'a-do'a Islami yang diambil dari sumber-sumber kitab Islam yang dikembangkan atas dasar aksesori ajaran Jawa lokal.

Berangkat dari perspektif Woodward di atas, dialektika agama Islam dan Jawa telah terjadi secara regeneratif sejak masuknya Islam ke tanah Jawa. Relasi keduanya telah menjadi tradisi baru, dimana potret tradisi yang 
merelasikan antar keduanya hingga kini tetap memiliki eksistensinya sendiri. Oleh karena itu, relasi keduanya tentu memiliki pola atau model tersendiri yang khas dan unik.

Berangkat dari dua perspektif teoretik yang sangat paradok tentang selamatan di atas, yaitu teori yang satu mengatakan bahwa selamatan adalah pembawaan agama asli Jawa (animis), sementara teori yang lainnya mengatakan bahwa selamatan adalah hasil tafsir dari ajaran agama Islam yang berpijak pada aksesoris lokal kejawen. Inilah antara lain yang melatar belakangi kajian ini dilakukan. Selanjutnya problematika akademik yang spesifik ini mendorong dilakukannya kajian lapangan menyangkut upaya penelusuran asal muasal munculnya terminologi selamatan pada lokus penelitian Desa Ngajum Malang. Secara lebih fokus rumusan masalah dalam penelitian ini adalah "bagaimana pola dialektika agama dan budaya dalam kasus ritual selamatan pernikahan adat Jawa di Ngajum Malang”.

\section{Pola Dialektika Agama dan Budaya dalam Ritual Selamatan Pernikahan Adat Jawa di Ngajum Malang}

Di antara beberapa ritual penting dalam proses adat pernikahan Jawa adalah ritual selamatan. Masyarakat Jawa pada umumnya berpandangan bahwa ritual selamatan adalah ritual suci yang keberadaannya menjadi penentu mengenai sukses tidaknya hajat kehidupan manusia itu.

Karenanya, mayoritas antropolog yang mempelajari budaya masyarakat Jawa sependapat bahwa tradisi selamatan adalah jantung keagamaan dari agama Jawa (Beatty,2001: 39). Sebagaimana statemen Geertz di atas, bahwa di setiap pusat keseluruhan sistem agama Jawa, pasti terdapat sebuah ritus yang formal, sederhana, dan jauh dari keramaian, ritus itu adalah ritus selamatan (Geertz, 1960: 11).

Cara pandang ini sangat dominan dalam mentalitas mereka, karena pemahaman hidup dalam perspektif filosofi kejawen adalah selamat. Sementara keselamatan itu akan diperoleh manusia jika dalam kehidupannya, mereka senantiasa eling (dzikr), percaya (iman), lan mituhu (tha'at) terhadap sang Pencipta. Konsep eling, pracaya, dan mituhu ini menjadi bagian dari ajaran delapan dasar (hastasila) dalam tradisi kehidupan orang Jawa yang lebih menekankan pada dua arah tujuan hidup (Endraswara. 2006: 93), yaitu arah transendental-ketuhanan, dan arah horizontal-kemanusiaan.

Untuk membangun pola relasi intensif antara manusia dan Tuhannya, 
antara manusia dengan sesama, orang Jawa menciptakan suatu ritme ritus yang sarat nilai transendental dan horisontal, yaitu ritus selamatan. Atas dasar pandangan di atas, selamatan memang menjadi ajaran agama Jawa yang sangat fundamental. Karenanya, Geertz tetap beranggapan kuat bahwa tradisi selamatan adalah ritual asli/ inti agama Jawa yang berakar dari tradisi pedesaan animis, (Beatty, 2001: 41-42) dan produk interpretasi teks-teks Islam dan tindakan ritual yang dikenali dan disepakati bersama oleh orang-orang muslim yang lebih luas (Woodward, 1988: 54-89).

Selamatan, sekurang-kurangnya di Jateng, tidak secara khusus atau bahkan pada dasarnya bukan ritus pedesaan, melainkan model pemujaan kerajaan, dalam hal ini adalah Kraton Yogyakarta. Dimana ritus itu lebih difahaminya sebagai tindakan keagamaan yang terinspirasi oleh para sufi (Woodward, 1988: 85). Dengan kata lain bahwa bentuk maupun makna selamatan berakar dari islam tekstual.

Kedua teori selamatan yang dikemukakan oleh dua pakar antropolog di atas menggambarkan konstruksi teoretik yang paradoksal. Teori pertama menggambarkan selamatan sebagai ritual inti masyarakat Kejawen yang berakar dari animis, sedangkan pada teori kedua selamatan lebih dipandang sebagai hasil interpretasi dari teks-teks keagamaan Islam. Sesuai dengan hasil temuan penelitian, terkait dengan pola dialektika agama dan budaya lokal tentang ritual selamatan pada pernikahan adat Jawa di Ngajum Malang, maka hasil penelitian ini dapat mengantarai dua model konstruk teoretik di atas yang sama-sama ekstrim.

Berdasarkan hasil temuan penelitian yang ada, secara substansial tindakan ritual yang mirip dengan selamatan itu dijumpai di keseluruhan sistem ritual yang ada di Jawa. Hanya saja keseluruhan sistem ritual yang ada di Jawa dalam hasil temuan penelitian ini, tidak dijumpai istilah selamatan sebagai term baku yang berasal dari agama Jawa, mayoritas subjek penelitian dan informan yang berhasil diinterview dan diobservasi mengatakan bahwa selamatan adalah hasil metamorfosis dari ritual lain, yang lebih popular dengan istilah ritual sesajenan.

Adalah terma baru yang diinterpretasikan dari teks-teks keagamaan Islam yang berpijak dari aksesori ritual kejawen, yaitu ritual sesajenan. Dengan demikian istilah selamatan itu sendiri adalah hasil pergeseran makna antropologis-filologis yang sangat panjang dan melelahkan dari ritual sesajen itu. Oleh karena itu, pergeseran makna antropo-teologis-filologis dari ritual sesajen hingga selamatan, bukanlah pergeseran yang sederhana, apalagi 
pergeseran-pergeseran humanis lainnya.

Dulu, ritual sesajen yang secara ritual memiliki maksud dan makna yang hampir sama dengan selamatan, dalam faktanya lebih banyak menekankan pada ranah-ranah emosional. Dimana benda-benda fisik ritual sesajian secara umum diperuntukkan kepada makhluk-makhluk ghaib yang sangat varian, baik para arwah leluhur, jin, danyang, dewa, hingga gusti engkang akariyo jagad. Suatu proses keyakinan teologis yang tidak menentu dan tanpa pijakan sistem nilai (pattern for behavior) yang jelas dan rasional. Keyakinan mereka selalu hadir pada semua sudut dan ruang budaya tertentu yang berpotensi memberikan makna bagi realitas kehidupan mereka.

Di tempat dan ruang budaya semacam itu pula, telah diyakini terdapat sebuah power atau kekuatan yang dapat memberikan berkah. Di tempat itu pulalah biasanya secara perlahan telah menjadi ruang budaya sakral, baik sebagai tempat-tempat pemujaan yang keramat maupun tempat upacara ritual selamatan yang lainnya. Dengan kata lain, tempat yang berpotensi memberikan sumber ketenangan, sumber kehidupan, maupun sebaliknya, yaitu sebagai sumber yang banyak menimbulkan marabahaya, maka di tempat itu pula muncul keyakinan mitos. Pada saat yang sama mereka meyakini bahwa alam sebagai subjek. Inilah awal mula munculnya cara pandang irrasional, dan bukan sebaliknya, yaitu alam sebagai objek, cara pandang yang rasional.

Sebuah proses keyakinan teologis yang sangat natural dan spekulatif, karena dalam praktiknya masih dalam proses pencarian kebenaran. Personifikasi ketuhanan mereka secara simplifikatif cenderung diwujudkan dalam bentuk wujud-wujud fisik yang kongkrit. Berawal dari sinilah, tidak jarang tuhan mereka beralih wujud menjadi tuhan matahari, tuhan bumi, tuhan angin, tuhan api, tuhan laut, dan banyak lagi jenis-jenis tuhan lain yang secara kongkrit dapat dilihat secara kasat mata. Atas dasar itu, tidak salah jika dalam praktiknya keyakinan teologis mereka yang sangat mengandalkan pendekatan emosional, banyak yang menyimpang dan tersesat ke dalam perjalanan imajinatif-esoterik yang banyak melakukan pengulangan-pengulangan kesalahan. Sebab, semua yang berada dalam kategori ghaib dan sakral dipersonifikasikan sebagai Tuhannya.

Namun demikian, keadaan ini bagi para penyebar Islam ketika itu tidak dianggap sebagai problem keagamaan yang serius, sebab pada hakikatnya mereka semua telah memiliki kesadaran ketuhanan yang luar biasa sesuai dengan cara pandang kosmologi keagamaan natural mereka. Oleh karena itu, dalam hal berdialektika antara dua entitas yang berbeda secara eksoterik ini, para da'i 
tidak bermaksud untuk melakukan perubahan-perubahan revolusioner terhadap konstruk budaya keagamaan mereka, terlebih menghilangkan budaya yang telah ada sebelumnya. Para wali tersebut bersifat sangat akomodatif dan kolaboratif dalam berda'wah, yaitu menerima atau membiarkan berlakunya sebuah tradisi atau adat yang telah berkembang lalu melanjutkan dan menyempurnakan dalam arti memberikan spirit nilai-nilai keagamaan Islam secara bertahap. Cara inilah yang disebut sebagai model dialektika teologis-kompromistik. Dialektika teologis-kompromistik ini dilakukan untuk melakukan reformulasi teologi dari yang bersifat sangat emosional menuju teologi yang rasional. Sebuah reformulasi yang tidak bermaksud mengubah paradigma teologi dan ritualitas keagamaan sebelumnya, melainkan memberikan sentuhan-sentuhan nilai teologi rasional dengan menawarkan term-term identik lain yang berupaya menyempurnakan makna teologi secara universal.

Dengan kata lain, teologi kompromistik adalah teologi yang telah mengalami proses kompromisasi antara teologi yang benar-benar terjadi secara emosional-naturalistik, yaitu teologi yang dialami dan dirasakan oleh komunitas masyarakat yang tidak memiliki pedoman agama yang resmi, berkolaborasi dengan teologi rasional formalistik, yaitu teologi yang berbasis pada ajaran formal keagamaan yang besar, dengan menjadikan term-term baru islam (selamatan, hajatan, dan tasyakuran) sebagai media mentransformasikan nilai-nilai teologi.

Secara riil, proses pergeseran teologi tersebut dapat dilihat pada akar historis praktik ritual sesajenan yang terjadi pada masyarakat Ngajum Malang. Dimana ritual sesajenan tersebut secara perlahan mengalami pergeseran makna teologis-filologis ke arah ritual selamatan, bahkan tidak hanya istilah selamatan yang identik dengan ritual sesajen tersebut, melainkan juga istilah hajatan, dan syukuran. Sesuai dengan hasil temuan penelitian yang ada, selamatan memang berakar dari bahasa Arab dan ajaran Islam. Dilihat dari sisi maknanya, selamatan itu berasal dari istilah salima, yaslamu, salaamatan yang berarti selamat (Askar, 2009: 334). Selamat dalam artian kondisi dan sikap teologisnya. Secara teologis, istilah selamatan tersebut bermaksud memfokuskan dan menyelamatkan teologi mereka yang sangat plural (polities) ke dalam teologi yang tunggal (monoteis), yaitu keyakinan yang hanya tertuju kepada Allah, Tuhan yang mahaesa, yaitu Tuhan yang menciptakan kehidupan ini.

Selain istilah selamatan juga istilah haajatan yang berasal dari akar kata haaja, yahuuju, hawjan, wahaajatan yang berarti butuh atau perlu. Seseorang yang mengadakan ritual hajatan, secara teologis berarti orang yang membutuhkan dan 
memerlukan respon Allah SWT., dari sejumlah kebutuhan yang tersembunyi dalam batin mereka. Perubahan istilah ini diharapkan bahwa semua kebutuhan apapun yang dicita-citakan manusia hendaknya diarahkan dan difokuskan permohonannya kepada Allah SWT.

Sementara itu, ritual sesajen dalam perkembangannya juga mengalami pergeseran makna menjadi istilah syukuran. Syukuran adalah kata benda yang berasal dari kata syakara, yasykuru, syukuuran yang berarti berterima kasih. Istilah inipun secara teologis-rasional juga dimaksudkan agar manusia itu selalu berterima kasih kepada Allah SWT. Sebab orang yang selalu bersyukur kepada Allah akan mendapatkan imbalan yang berlipat ganda dari Allah SWT (QS. Ibrahim 14: 7). Dengan sikap ini, maka diharapkan orang yang melakukan ritual syukuran adalah hanya semata-mata karena berterima kasih atas rahmat yang telah diberikan Allah kepadanya.

Pergeseran terminologi filologis dari sesajenan menjadi selamatan, hajatan dan syukuran bukanlah pergeseran tanpa kepentingan atau makna, proses pergeseran itu menurut hasil penelitian lapangan merupakan pergeseran yang terencana dan bertujuan yang dilakukan oleh para da'i Islam yang sangat kolaboratif dan antroposentris, guna merubah paradigma teologi mereka yang cenderung sangat emosional-naturalistik menjadi paradigma teologi yang rasional-formalistik

Berbeda dengan istilah selamatan, hajatan, dan syukuran, istilah sedekahan dan barakahan yang merupakan hasil metamorfosis dari istilah ritual sesajen lebih menekankan pada pergeseran nilai-nilai teologis-humanistik pada pelaku ritualnya. Praktik ritual sesajen dulu pada umumnya adalah ritualitas yang lebih berorientasi pada kebutuhan personal. Benda-benda sebagai media ritual sesajen seusai pelaksanaan ritualan, cenderung dibuang (sesajen bucalan) dan tidak dimanfaatkan untuk kepentingan orang lain.

Sejak masuknya para wali sebagai penyebar ajaran Islam, Islam berupaya mengapresiasi kegiatan itu dan merekonstruksinya serta menyempurnakannya dengan cara menciptakan dampak manfaat ritual sesajenan tersebut bagi kehidupan manusia secara sosial. Oleh karenanya, istilah ritual sesajen juga mengalami pergeseran ke istilah ritual sedekahan. Istilah itu berasal dari akar kata shadaqa, yashduqu, shidqan washadaqatan yang berarti bersedekah. Sejak itu, praktik ritual sesajen, telah mengalami pergeseran makna menjadi teologis-humanistik, yaitu praktik ritual yang memberikan efek secara langsung bagi kesadaran sosialnya, dari yang bersifat personal-individualistik menjadi sosial-komunalistik.

el Harakah Vol.15 No.1 Tahun 2013 
Jika dahulu benda-benda sesajen yang berupa hasil-hasil pertanian, seusai ritual cenderung tidak disedekahkan secara sosial, maka setelah ritual itu berkolaborasi dengan nilai-nilai ajaran Islam, benda-benda sesajen yang digunakan untuk ritual sesajenan diutamakan untuk disedekahkan kepada orang lain. Bermula dari proses kronologis inilah, semua oleh-oleh/bawaan yang diberikan oleh pemilik hajat (shahibul hajat) kepada orang yang diundang hajatan disebut dengan berkat/berkatan.

Oleh karenanya, sepulang dari acara ritual selamatan atau hajatan dalam masyarakat Jawa, orang akan membawa oleh-oleh/bawaan yang dinamakan dengan berkat. Istilah berkat pada dasarnya berasal dari kata baraka, yabruku, barkatan yang berarti tumbuh/tambah/bahagia. Istilah ini telah dipilih dan dipopulerkan oleh para wali untuk menggantikan ritual sesajen, karena maksud dan tujuannya yang sangat mulia. Dimana, secara humanis, mereka yang memberikan oleh-oleh itu, dianggap sebagai orang yang memiliki kepekaan sosial yang tinggi. Untuk benda-benda sesajen yang diberikan kepada orang lain akan memiliki nilai tambah dan berkah, sebab ia dapat dimanfaatkan kepada mereka yang sangat membutuhkan, selain itu ia juga dapat menyebabkan munculnya kebahagiaan orang lain. Alasan inilah yang secara natural dapat diterima oleh masyarakat kejawen pada umumnya, karena pada hakikatnya terdapat kesamaan-kesamaan fundamental dengan ajaran kejawen.

Dengan demikian, selamatan bagi masyarakat Islam-Kejawen adalah versi upacara keagamaan yang melambangkan kesatuan mistis dan sekaligus kesatuan sosial. Enkulturisasi Islam terhadap budaya lokal dalam konteks ritual sesajen pada pernikahan adat Jawa khususnya, memiliki kontribusi holistik, baik secara teologis-kompromistik maupun secara teologis-humanistik.

Kontribusi teologis-kompromistik tersebut dapat dilihat pada pola pergeseran dari teologi emosional-naturalistik ke teologi yang sangat rasionalformalistik, yaitu logika ketuhanan yang dapat diterima oleh akal sehat secara kompromistik. Kontribusi teologis-humanistik juga dapat dicermati dari perilaku personal-individualistik ke sikap sosial-komunalistik.

Dari pola dialektika Islam dan Kejawen tersebut secara otomatis telah merubah pemahaman ke arah pemahaman baru dan ritual baru, yaitu ritual selamatan yang berpijak pada sistem nilai Islam-kejawen. Dengan demikian makna ritual selamatan berubah makna yang sangat mendalam, yaitu ritual yang melibatkan relasi vertikal dan horizontal.

Relasi kesadaran berketuhanan dan relasi kesadaran berkemanusiaan, baik dari kalangan handai tolan, tetangga, rekan kerja, sanak keluarga, 
maupun nenek moyang yang telah meninggal. Semuanya duduk bersama mengelilingi satu ruang dan arena yang terikat dalam kelompok sosial tertentu yang diwajibkan untuk tolong-menolong dan bekerja sama. Selamatan juga merupakan media untuk mempertemukan berbagai aspek kehidupan sosial dengan suatu cara untuk memperkecil ketidakpastian, ketidakseimbangan, maupun konflik (Geertz, 1989: 13).

Ritual selamatan, hajatan, syukuran, sedekahan, dan berkatan, yang merupakan produk baru dari proses dialektika yang melelahkan antara Islam dan Kejawen, mempersonifikasikan sebuah potret ritual yang betul-betul memiliki efek holistik, baik secara teologis maupun humanis. Inilah sebabnya, Mark mengatakan bahwa dialektika Islam dan Jawa terjadi secara regeneratif, sejak masuknya Islam ke tanah Jawa hingga sekarang ini. Tentunya, relasi keduanya juga telah menjadi tradisi baru tersendiri, dimana potret tradisi yang merelasikan antar keduanya hingga kini tetap memiliki eksistensinya sendiri. Oleh karena itu, relasi keduanya memiliki pola tersendiri yang khas dan unik.

\section{Simpulan}

Kajian yang bermaksud melihat pola dialektika agama dan budaya dalam kasus ritual selamatan pada pernikahan adat Jawa di Ngajum Malang ini, secara umum menemukan dua pola dialektika yang berbeda. 1). Pola Dialektika Teologis-Kompromistik (Emosional-Rasional) dan 2). Pola Dialektika Teologis-Humanistik (Personal-Sosial). Masing-masing pola dialektika di atas memiliki paradigma dan karakteristik yang berbeda.

Pola dialektika yang pertama, adalah pola dialektika yang menghasilkan pergeseran teologis dari yang bersifat emosional-naturalistik menuju teologi yang bersifat rasional-formalistik. Teologi yang bersifat emosional-naturalistik adalah teologi yang banyak mengandalkan kepekaan rasa emosional, yang jauh dari pertanyaan-pertanyaan kritis-filosofik. Teologi yang bersifat rasionalformalistik adalah teologi yang berhujjah dan beralasan. Hal ini merupakan proses pendewasaan teologi melalui diskursus ilmiah, yang sarat dengan berbagai argumentasi kritis-objektif-filosofik. Perlu menciptakan kedewasaan keimanan melalui dialog secara intens dengan berbagai fenomena sosial yang berkembang secara dinamis. Pada proses pergeseran teologi yang dimaksud di atas adalah pergeseran secara kompromistik.

Pola dialektika kedua, adalah pola dialektika teologis-humanistik, yaitu pergeseran perilaku dari pola yang bersifat personal menuju pola perilaku yang bersifat sosial. Pola perilaku yang bersifat personal adalah pola perilaku 
yang banyak mempertimbangkan kebutuhan individual. Ritual selamatan banyak diukur nilai manfaatnya semata-mata dalam perspektif kepentingan individu. Pola perilaku yang bersifat sosial adalah pola perilaku yang banyak mempertimbangkan manfaat sosialnya. Paradigma pola perilaku sosial ini senantiasa berfikir untuk kepentingan manusia secara komunal dan bukan individual.

Karena itu, dua pola hasil temuan penelitian di atas, jika digambarkan secara lebih rinci seperti dalam tabel berikut:

Tabel Pola Dialektika Agama dan Budaya dalam Kasus Ritual Selamatan pada Pernikahan Adat Jawa di Ngajum Malang

\begin{tabular}{|l|l|l|l|}
\hline No & Asal Ritual & $\begin{array}{l}\text { Pola Dialektika dan Sifat } \\
\text { Dialektika Ritual Antara } \\
\text { Agama dan Budaya (Islam } \\
\text { dan Kejawen) }\end{array}$ & $\begin{array}{l}\text { Hasil Dialektika Ritual } \\
\text { antara Agama dan Budaya } \\
\text { (Islam-Kejawen) }\end{array}$ \\
\hline 1 & Ritual Sesajen & $\begin{array}{l}\text { Teologis-Kompromistik } \\
\text { (Emosional-naturalistik ke } \\
\text { Rasional-formalistik) }\end{array}$ & $\begin{array}{l}\text { Ritual Selamatan } \\
\text { Ritual Hajatan } \\
\text { Ritual Syukuran }\end{array}$ \\
\hline 2 & Ritual Sesajen & $\begin{array}{l}\text { Teologis-Humanistik } \\
\text { (Personal-individualistik ke } \\
\text { sosial-komunalistik) }\end{array}$ & $\begin{array}{l}\text { Ritual Sedekahan } \\
\text { Ritual Barokahan/ Ritual } \\
\text { Berkatan }\end{array}$ \\
\hline
\end{tabular}

Sumber: Analisis penulis 2012

\section{Daftar Pustaka}

Askar, S. 2009. Kamus Arab-Indonesia al-Azhar. Jakarta: Senayan Publising.

Beatty, Andrew. 2001. Variasi Agama di Jawa: Suatu Pendekatan Antropologi. Jakarta: Raja Grafindo Persada.

Endraswara, Suwardi. 2006. Falsafah Hidup Jawa. Cakrawala: Yogyakarta.

Geertz, Clifford. 1960. The Religion of Java. Glencoe: The Free Press.

Geertz, Clifford. 1989. Abangan, Santri, Priyayi dalam Masyarakat Jawa. Terj. Aswab Mahasin. Jakarta: PT.Pustaka Jaya.

Gus Sofwan, 2011. Wawancara tanggal 22 Agustus 2011.

Pranowo, Bambang. 1998. Islam Faktual Antara Tradisi dan Relasi Kuasa. 
Yogyakarta: Adi Cita Karya Nusa.

QS: Ibrahim. 1971. Al Quran dan Terjemahannya. Jakarta: Yayasan Penyelenggara Penerjemahan.

Woodward, Mark. 1988. The Slametan: Textual Knowledge and Ritual Performance in Central Javanese Islam. History of Religion.

el Harakah Vol.15 No.1 Tahun 2013 